\title{
Errors on Ghanaian Students' Written English: Is Speaking School Pidgin English the Cause?
}

\author{
Evershed Kwasi Amuzu \\ Department of Linguistics \\ School of Languages \\ University of Ghana \\ Legon \\ a evershed@yahoo.com \\ and \\ Ebenezer Asinyor \\ Department of Linguistics \\ School of Languages \\ University of Ghana \\ Legon \\ DOI//http://dx.doi.org/10.4314/gjds.v13i2.3
}

\begin{abstract}
This paper highlights the situation in Ghana (and most likely also in Cameroon) where English is learned and used as a second (and official) language alongside varieties of an Englishrelated pidgin and where the speaking of the pidgin is routinely blamed for errors that learners of English, especially those in secondary and tertiary institutions, commit in their speech and writing. Specifically, the paper investigates the justification for attributing errors that educated Ghanaians commit in their written English to the School Pidgin English (SPE) some of them speak. A case study was carried out in a diploma awarding institution. Two groups of students, students identified as speakers of SPE and students identified as non-speakers of SPE, were asked to write an essay on a given topic and the grammatical and spelling errors they committed were identified and scrutinized. It emerged that none of the types of errors identified was exclusively committed by the SPE speakers, a finding which suggests that there is hardly a definite causative relationship between speaking SPE and committing the errors. Rather, it is found that the errors are more directly related to some grammatical features of the students' mother tongues and to certain writing systems they use on electronic media platforms. The logical conclusion drawn is that the learning of English in Ghana (and most likely also in Cameroon) may improve if teachers are guided by these more plausible causes of their students' problems when they try to help them.
\end{abstract}

2. Corresponding author: Evershed Kwasi Amuzu 
Keywords: Pidgin English, Grammatical Errors, Interference, Language Contact, Second Language Learning / Acquisition

\section{Introduction}

Ghanaian Pidgin English (GhPE), a variety of West African Pidgin English, has received considerable scholarly attention in recent years (e.g. Amoako 1992; Forson 1996; Huber 1999, Dzameshie 2001; Frimpong 2012; Dako 2002a ,2002b, 2013a, 2013b; Dako \& Yitah 2012; Osei-Tutu 2008; Wiredu 2013). Two varieties of GhPE are recognized: 'Uneducated Pidgin' (UP) and 'Educated Pidgin', which is also known as 'School Pidgin English' / SPE. The distinction between the two varieties is basically functional; they are not distinguishable structurally (Huber 1999). UP functions chiefly as a lingua franca in multilingual immigrant settlements in southern Ghanaian cities known for poverty and widespread lack of education while SPE, usually identified with male students in secondary schools and tertiary institutions, functions as a sociolect (Huber 1999; Dako 2002a, 2002b).

Attitudes toward especially GhPE have been largely negative. One of the earliest references to it is in Sey (1973) which describes it as a variety associated with uneducated labourers who used it with their foreign masters. None of the varieties of GhPE is a welcome code at a typical formal gathering in Ghana (Desiree, 2004). The reason is simple: pidgin is not a standard variety of English; as noted it is associated with the uneducated, with people of low-status who are usually foreign members of the community (Dzameshie, 2001).

Backed by and fueled on by such negative attitudes toward pidgin, important members of the Ghanaian society routinely blame GhPE (also called "Broken English") for the poor performances of students in secondary and tertiary institutions in the country. For example, in a report by Huber (2014) on the use of pidgins and creoles in education in four West African countries, Sierra Leone, Ghana, Nigeria and Liberia, he mentions that some Ghanaian educationists see SPE as a dangerous creature. A case in point is Egblewogbe (1992) who asserted that the indiscriminate use of pidgin is leading the nation to illiteracy. The same report noted that in 1985 the Faculty of Pharmacy of the University of Science and Technology, Kumasi, formally proscribed the use of pidgin in its confines. In the same vein, Professor Asenso Okyere, an ex-Vice Chancellor of the University of Ghana, cautioned the 2002/2003 fresh students against the use of SPE noting that it would be harmful to their academic performance (Rupp, 2013). This kind of academic interest in pidgin is not unlike what obtains in Cameroon. In 2006, the University of Buea, Cameroon, mounted a campaign against pidgin and erected sign boards around campus that bore the following inscriptions (Eta, 2006). 
NO PIDGIN ON CAMPUS, PLEASE!

BE MY FRIEND. SPEAK ENGLISH

PIDGIN IS TAKING A HEAVY TOLL ON YOUR ENGLISH. SHUN IT

IF YOU SPEAK PIDGIN, YOU WILL WRITE PIDGIN

Indeed, each year, chief examiners of West African Senior High School certificate examinations on 'Core English' issue damning reports pointing to poor and deteriorating performances in the examinations. For example, in summarizing candidates' weakness in the English language, the Chief Examiners' reports of the May/ June 2013 examination state:

Most of the candidates have... not grasped the basic workings of the language; hence, their structures are faulty. They are on the whole, not observing the various rules of agreement, i.e. subject with the attendant verbs, pronouns, number and gender (2013 May/June WASSCE, ${ }^{3}$ page 9).

Some examples cited in the report are reproduced below. The problem areas are in bold.

- Such a hawker do not know how to keep the street tidy.

- She was giving a beautiful dress by his father.

- The teacher is now given the pupils exercise books.

It is in the light of such reports that some English teachers in the Senior High Schools in Ghana point accusing fingers at SPE (and not to their own failings, for example) as the primary cause of their students' problems. This attitude of teachers is reflected in the following report by Huber (1999: 147):

As teachers fear Pidgin will have an adverse effect on their pupils' performance, its use is strongly discouraged in class, but boys freely resort to it in the school-yard and when unobserved by members of the teaching staff.

Ironically, some other persons pointedly indict teachers as the bad role models (i.e. being notorious speakers of SPE) which students copy. Such an indictment is reported by Adika (2012: 161):

GhaPE [i.e. SPE] is sometimes blamed for the falling standard of English language usage among Ghanaian students. Indeed, a senior minister of state, Mr. J.H. Mensah is reported to have attributed the poor academic

3. West Africa Senior School Certificate Examination 
performance in some second cycle educational institutions to the way some teachers and students communicate in Pidgin English. His argument was simply that since students consider the habit of their teachers as the best, when the students hear them use Pidgin English to converse, the students emulate them and the practice then becomes part of their lives. The minister of state advised teachers to speak the Queen's English at all times to inspire their students to learn to do the same, (21 February 2005, Daily Graphic).

Students themselves hold divergent views about SPE. By the time they arrive at the university or the polytechnic, many of them have become convinced that SPE is indeed a problem language variety as far as their academic careers are concerned. At the University of Ghana, Dzameshie (2001) interviewed some students about why they do not use SPE. Many expressed the fear that it would ruin their English, their character and their personality. Some even noted that SPE is unrefined, deviant, uncivilized and should not be encouraged. About ten years after Dzameshie's paper, Dako (2013b) also observed that even now that it seems that people's attitude toward SPE is changing (i.e. becoming more positive), a woman who speaks SPE may still raise doubts about her morality.

However, Dzameshie's (2001) study also provides details of the positive attitude that 'lovers' of SPE have for this variety of language. In his interviews, SPE-speaking students, who were mostly male, explained that they use pidgin because it is more expressive than Standard English; that it creates a sense of belonging; that it is a means of in-group acceptance and that it is fun. Dzameshie deduces from the responses of his male subjects that they have a positive attitude towards pidgin because the code is associated with being tough men; and they entertain no fear that the code is detrimental to academic performance in English.

There are therefore two views about whether pidgin in Ghana has adverse influence on the English of pidgin speakers: the popular opinion that it does and the (mainly male) pidgin speakers' own opinion that it does not. This paper sets out to match these opinions against empirical facts. It therefore asks the following research questions.

- Is there any empirical evidence that there is a causative relationship between speaking SPE and committing grammatical and spelling errors in written Standard English?

- If there is no (or only negligible) evidence of a causal link between speaking SPE and committing grammatical and spelling errors in written English, what are the real causes of such errors? 
This study will not address any issues related to errors committed in spoken English by the respondents. In considering these questions, the paper seeks to highlight the situation in countries like Ghana and Cameroon where English is learned and used as a second (and official) language in a language contact context where some of its speakers also speak a form of pidgin English actively thus causing the suspicion that there is a causative relationship between speaking the pidgin and committing grammatical and other errors in English.

\section{Methodology}

Data for this study were collected at Koforidua Polytechnic, a diploma-awarding institution in the Eastern Region of Ghana. ${ }^{4}$ Thirty (30) final-year students were asked to write an essay on the topic "Is Koforidua Polytechnic ready to become a polytechnic university?" This topic was chosen because its subject matter was the most sensational item in discussions on the campus at the time as the government had announced the intention of converting polytechnics into universities in coming years. Final year students were selected because (at the time of data collection for this paper, close to the end of the second semester) they would have spent two and half years at the tertiary level since leaving secondary school. Two groups were constituted: 15 SPEspeaking students and 15 non-SPE-speaking students. An SPE-speaking student must have been heard using SPE on campus or must have been identified as an active user of SPE by another such speaker. The 15 students were carefully selected after peer group accreditation from an initial pool of 24. Similarly, from an initial pool of 26 students who claimed to be people who could not speak SPE, 15 were selected after a wide consultation about their language use habits around campus. The 15 SPE-speaking students were all male students, for no female identified herself or was identified as a speaker of SPE. The non-Speaking group comprised 10 female students and 5 males.

The essays were collected the same day the students wrote them. Each script was marked and problematic sentences, in terms of grammar and spelling, were square-bracketed without exposing what the problems were. A photocopy of each student's marked script was returned to him/her with the instruction that they identify the errors and to selfcorrect them. The rationale for this method was to distinguish mistakes (blemishes the writer can identify and fix without assistance) from genuine errors (blemishes the writer is unable to recognize let alone fix by himself/herself). ${ }^{5}$

\footnotetext{
4. This institution has since been elevated to the status of university.

5. See Anyidoho (2002) for a similar approach.
} 
In section 3, statistics of the errors identified are presented and in section 4 the implications of the findings are discussed. As will become clear especially in section 4, there was not a single kind of error that was exclusively committed by SPE speakers, which suggests that there is hardly a strong causative relationship between speaking SPE and committing errors in written English. This finding leads later, in that section, to a search for more plausible causes of some of the errors identified. Section 5 provides some concluding remarks.

\section{Results}

The essay scripts of both the SPE speakers and the non-SPE speakers were marked and checked for morphosyntactic and spelling errors, the kinds of error routinely attributed to SPE. Samples of errors found in the scripts of SPE speakers are categorized in Table 1 while the same thing is done with errors found in the scripts of non-SPE speakers in Table 2. The problem areas are in bold. 
Table 1: Samples of SPE speakers' errors

\begin{tabular}{|c|c|c|}
\hline Code & Categorization & Errors \\
\hline WPP & $\begin{array}{l}\text { Wrong Use of Past } \\
\text { Participles }\end{array}$ & Lecturers are not even been paid well. \\
\hline OPM & $\begin{array}{l}\text { Omission of Possessive } \\
\text { Markers }\end{array}$ & $\begin{array}{l}\text { First of all, the Polytechnic has the aim of training it students to } \\
\text { become professionals. }\end{array}$ \\
\hline CE & Concord Errors & A polytechnic is an institution that train students... \\
\hline WCN & $\begin{array}{l}\text { Wrong Use of Collective } \\
\text { Nouns }\end{array}$ & Personnel include teaching and non-teaching staffs. \\
\hline $\mathrm{PNC}$ & $\begin{array}{l}\text { Proper Nouns not } \\
\text { Capitalized }\end{array}$ & $\begin{array}{l}\text { In conclusion, koforidua polytechnic is not ready to become a } \\
\text { polytechnic university. }\end{array}$ \\
\hline ST & Sequence of Tenses & $\begin{array}{l}\text { The first time I saw the polytechnic, I was very excited and I know } \\
\text { it can become a university. }\end{array}$ \\
\hline OPLM & $\begin{array}{l}\text { Plural Markers } \\
\text { Omitted }\end{array}$ & $\begin{array}{l}\text { This is obvious that when graduate from these Polytechnic go for } \\
\text { interviews with other university graduate... }\end{array}$ \\
\hline WC & Wrong Capitalization & $\begin{array}{l}\text { Basically, } \boldsymbol{T} \text { he form of platforms that... } \\
\text { Students with such ideas are pushed over anytime they present } \\
\text { such ideas to the } \boldsymbol{G} \text { overnment to help initiate... }\end{array}$ \\
\hline $\mathrm{OA}$ & Omission of Articles & $\begin{array}{l}\text { The polytechnic is ready to become _ university because of its } \\
\text { facilities. }\end{array}$ \\
\hline WS & Wrong Spelling & $\begin{array}{l}\text { I there urge the government to solve the many problems of the } \\
\text { polytechnic. }\end{array}$ \\
\hline WPU & $\begin{array}{l}\text { Wrong Part of Speech } \\
\text { Used }\end{array}$ & $\begin{array}{l}\text {.. after their graduation, because their sometimes not totally fit in } \\
\text { the job market... }\end{array}$ \\
\hline DUP & $\begin{array}{l}\text { Deviant Use of } \\
\text { Prepositions }\end{array}$ & $\begin{array}{l}\text {... after their graduation, because their sometimes not totally fit } \\
\text { in the job market... }\end{array}$ \\
\hline DNA & $\begin{array}{l}\text { Determiner-Noun } \\
\text { Agreement }\end{array}$ & Some of this private hostels... \\
\hline
\end{tabular}


Table 2: Samples of non-SPE Speakers' errors

\begin{tabular}{|c|c|c|}
\hline Code & Categorization & Errors \\
\hline WPP & $\begin{array}{l}\text { Wrong Use of Past } \\
\text { Participles }\end{array}$ & I think the polytechnic is not ready to be change to university... \\
\hline OPM & $\begin{array}{l}\text { Omission of } \\
\text { Possessive Markers }\end{array}$ & $\begin{array}{l}\text { Koforidua polytechnic is a tertiary institution which most of it } \\
\text { activities is technical ... }\end{array}$ \\
\hline $\mathrm{CE}$ & Concord Errors & All the universities in the country does not accept D7, E8 ... \\
\hline WCN & $\begin{array}{l}\text { Wrong Use of } \\
\text { Collective Nouns }\end{array}$ & Secondly, lack of tools and equipments. \\
\hline $\mathrm{PNC}$ & $\begin{array}{l}\text { Proper Nouns not } \\
\text { Capitalized }\end{array}$ & $\begin{array}{l}\text { The Koforidua Polytechnic located in the eastern region of the } \\
\text { republic of Ghana... }\end{array}$ \\
\hline ST & Sequence of Tenses & $\begin{array}{l}\text { It was by then Koforidua technical institute and turn into a } \\
\text { polytechnic later on. }\end{array}$ \\
\hline OPLM & $\begin{array}{l}\text { Plural Markers } \\
\text { Omitted }\end{array}$ & $\begin{array}{l}\text { Furthermore, there are not enough hostel to accommodate } \\
\text { students. }\end{array}$ \\
\hline WC & Wrong Capitalization & ... issues and problems concerning $\boldsymbol{A}$ cademics and other ... \\
\hline OA & Omission of Articles & _ Training the student receive equip them for __ job market. \\
\hline WS & Wrong Spelling & $\begin{array}{l}\text { These private universities are affiliated to some renound } \\
\text { universities. }\end{array}$ \\
\hline WP & Wrong Punctuation & $\begin{array}{l}\text { The polytechnic is also in a better position to be run as a university } \\
\text { for getting that, these private universities are affiliated to ... }\end{array}$ \\
\hline WPU & $\begin{array}{l}\text { Wrong Part of Speech } \\
\text { Used }\end{array}$ & $\begin{array}{l}\text { And since they were looking at the notice board for there various } \\
\text { timetables. }\end{array}$ \\
\hline DUP & $\begin{array}{l}\text { Wrong use of } \\
\text { Preposition }\end{array}$ & $\begin{array}{l}\text { Koforidua polytechnic is ready for the take off on government`s } \\
\text { policy to convert polytechnics into technical universities in } 2016 .\end{array}$ \\
\hline OS & Omission of subject & $\begin{array}{l}\text { Am a computer science student. } \\
\text { Though is good for a polytechnic to be a university, will it maintain } \\
\text { its Vocational subjects? }\end{array}$ \\
\hline DNA & $\begin{array}{l}\text { Determiner-Noun } \\
\text { Agreement }\end{array}$ & Until all this things are worked on ... \\
\hline
\end{tabular}

Frequency counts of each kind of errors are presented below in Table 3 (which captures data from non-SPE speakers) and in Table 4 (which captures data from SPE speakers). The figures in the second and third columns indicate whether the problems were selfcorrected by the students or not, and the last column shows the total number of the errors committed. Table 5 collapses Tables 3 and 4 for simplicity. 
Table 3: Analysis of non-SPE essays

\begin{tabular}{|l|l|l|l|}
\hline Code & Self-Corrected & Not Self-Corrected & Total Errors \\
\hline WPP & 10 & 1 & 11 \\
\hline OPM & 1 & 8 & 9 \\
\hline CE & 8 & 18 & 26 \\
\hline WCN & & 2 & 2 \\
\hline PNC & 4 & 1 & 5 \\
\hline ST & 2 & & 2 \\
\hline OPLM & 12 & 8 & 20 \\
\hline WC & 7 & 6 & 13 \\
\hline OA & 8 & 2 & 10 \\
\hline WS & 14 & 19 & 23 \\
\hline WP & 2 & 1 & 3 \\
\hline WPU & 4 & & 4 \\
\hline DUP & 3 & 2 & 5 \\
\hline OS & 1 & 4 & 5 \\
\hline DNA & 3 & & 3 \\
\hline
\end{tabular}

Table 4: Analysis of SPE essays

\begin{tabular}{|l|l|l|l|}
\hline Code & Self-Corrected & Not Self-Corrected & Total Errors \\
\hline WPP & 5 & 10 & 15 \\
\hline OPM & 4 & 2 & 6 \\
\hline CE & 12 & 11 & 23 \\
\hline WCN & 1 & 1 & 2 \\
\hline PNC & 1 & 1 & 2 \\
\hline ST & 3 & 1 & 4 \\
\hline OPLM & 14 & 9 & 23 \\
\hline WC & 3 & 4 & 7 \\
\hline OA & 1 & 3 & 4 \\
\hline WS & 14 & 10 & 24 \\
\hline WPU & 3 & 1 & 4 \\
\hline DUP & 3 & 2 & 5 \\
\hline DNA & 3 & & 3 \\
\hline
\end{tabular}


Table 5: Comparing SPE and non-SPE figures

\begin{tabular}{|c|c|c|c|c|c|c|}
\hline Code & $\begin{array}{l}\text { SPE Total } \\
\text { Number of } \\
\text { Errors }\end{array}$ & $\begin{array}{l}\text { Non-SPE } \\
\text { Total No. } \\
\text { of Errors }\end{array}$ & $\begin{array}{l}\text { SPE No. Self } \\
\text { - Corrected }\end{array}$ & $\begin{array}{l}\text { Non-SPE No. } \\
\text { Corrected }\end{array}$ & $\begin{array}{l}\text { SPE No. Not } \\
\text { Corrected }\end{array}$ & $\begin{array}{l}\text { Non-SPE } \\
\text { No. Not } \\
\text { Corrected }\end{array}$ \\
\hline WPP & 15 & 11 & 5 & 10 & 10 & 1 \\
\hline OPM & 6 & 9 & 4 & 1 & 2 & 8 \\
\hline CE & 23 & 26 & 12 & 8 & 11 & 18 \\
\hline WCN & 2 & 2 & 1 & & 1 & 2 \\
\hline $\mathrm{PNC}$ & 2 & 5 & 1 & 4 & 1 & 1 \\
\hline ST & 4 & 2 & 3 & 2 & 1 & \\
\hline OPLM & 23 & 20 & 14 & 12 & 9 & 8 \\
\hline WC & 7 & 13 & 3 & 7 & 4 & 6 \\
\hline OA & 4 & 10 & 1 & 8 & 3 & 2 \\
\hline WS & 24 & 23 & 14 & 14 & 10 & 19 \\
\hline WP & & 3 & & 2 & & 1 \\
\hline WPU & 4 & 4 & 3 & 4 & 1 & \\
\hline DUP & 5 & 5 & & 3 & 1 & 2 \\
\hline OS & & 5 & & 1 & & 4 \\
\hline DNA & 3 & 3 & 3 & 3 & & \\
\hline
\end{tabular}

The first point of comparison worthy of attention, which is indeed a summary of the situation, is that non-SPE speakers committed errors in all of the 15 categories while SPE speakers committed errors in 13 of the categories; i.e., while non-SPE speakers committed errors in OS and WP, SPE speakers did not commit any error in those categories. Bearing in mind that SPE speakers are supposed to be the ones who commit the most errors, this picture should caution the analyst to take a critical look at the details in these data. Detailed discussion of the data thus appears in the next section.

\section{Discussion}

Tables 3 and 4 show that generally both SPE and non-SPE speakers committed many types of morphosyntactic and spelling errors with almost equal regularity. The error types in question are WPP, OPM, WS, CE and OPLM. For example, regarding WPP errors, while SPE speakers had 15 of them non-SPE speakers had 11. Similarly, SPE speakers committed 6 OPM errors while non-SPE speakers committed 9. The WS, CE and OPLM categories were the highest number of error categories with SPE speakers making 24 in WS, 23 in CE and 23 in OPLM while non-SPE speakers made 23 in WS, 26 in CE and 20 in OPLM. 
As noted, the data collection method included finding out whether members of each group can or cannot self-correct the errors they have committed; it is reasoned that a student's inability to self-correct an error demonstrates that what is being dealt with is an error rather than just a mistake. As shown in Table 5, while SPE speakers corrected 14 out of 24 WS errors and 12 out of 23 CE errors, non-SPE speakers corrected 14 out of 23 WS errors and 8 out of $26 \mathrm{CE}$ errors. Comparing the two corrected $\mathrm{CE}$ figures, it is noticed that non-SPE speakers committed more errors and corrected fewer. This fact is revealing because it shows that it would be unfair to attribute CE errors in the students' essays to the fact that (some of) them speak SPE.

The attribution of blame to SPE for errors students commit in the writing of Standard English seems to be even less sustainable when one considers the details in Table 5 with regard to error categories OA, WC and OS. It is found that SPE speakers committed less of these error types than non-SPE-speakers. While SPE speakers committed 4 OA errors, non-SPE committed 10 and while SPE committed 7 WC errors, non-SPE committed 13. Significantly, while SPE did not commit any OS error, non-SPE committed 5 of such errors. It appears then that one needs to look elsewhere for factors that are probably more responsible for these errors, since academically there seems to be no difference between SPE speakers and non-SPE speakers. In fact, this observation mirrors the impression one gets when one compares scores obtained by the same SPE and non-SPE speakers in the end of first semester examination in Communication Skills (see the table below).The speakers/respondents took this examination as part of the class of final year students from which they had been selected for this project, and it is important to also note that this examination was conducted before the essay writing test they participated in for the project. The table displays the marks of each of the 15 SPE speakers and 15 nonSPE speakers. Note that on the average, there is no difference between SPE speakers' scores and those of the non-SPE speakers. 
Table 6: Examination results of SPE and non-SPE speakers

\begin{tabular}{|l|l|l|}
\hline S/N & $\begin{array}{l}\text { SPE Speakers } \\
100 \% \text { Mark }\end{array}$ & $\begin{array}{l}\text { Non-SPE Speakers } \\
100 \% \text { Mark }\end{array}$ \\
\hline 1 & 65 & 59 \\
\hline 2 & 63 & 66 \\
\hline 3 & 53 & 70 \\
\hline 4 & 56 & 63 \\
\hline 5 & 70 & 70 \\
\hline 6 & 82 & 69 \\
\hline 7 & 57 & 55 \\
\hline 8 & 78 & 70 \\
\hline 9 & 54 & 67 \\
\hline 10 & 62 & 58 \\
\hline 11 & 66 & 76 \\
\hline 12 & 71 & 45 \\
\hline 13 & 55 & 80 \\
\hline 14 & 76 & 73 \\
\hline 15 & 71 & 61 \\
\hline Average & 65.3 & 65.5 \\
\hline & & \\
\hline
\end{tabular}

It is therefore pertinent to search for the more likely sources of the errors that both groups commit as it does not seem exclusively to be the speaking of School Pidgin English.

It is widely known in the literature that one's first language (L1) usually interferes with one's second language (L2). For instance, Ghanaian languages do not show number agreement between a syntactic subject and a verb the way English does. This is shown in the following Ewe examples:

(1) Kofi fo-na no vi-a-wo gbesiagbe

K. beat-HAB sibling-DEF-PL every day

'Kofi beats his siblings every day.'

(2) Kofi kple Kwame fo-na wo-nכ vi-wo gbesiagbe

Kofi and Kwame. beat-HAB .3PL-sibling-PL everyday 'Kofi and Kwame beat their siblings every day.' 
In the two examples above, the verb fo "beat" inflects similarly with the habitual marker - na despite the fact that the subject-NP is singular in (1) but plural in (2). In the English translations, however, note that in (1) beat takes the third person singular marker -s to agree with the singular subject-NP 'Kofi' but takes no inflection in (2) to signal plurality agreement with the plural subject-NP 'Kofi and Kwame'. The same situation obtains in Akan. For instance, note that in examples (3) and (4), from the Twi variety of Akan, the same forms of the verb nim 'know' and $\boldsymbol{y \varepsilon}$ 'do' are used despite the fact that their subjectNPs are singular in (3), namely akwaraa 'child' and 0 (3sg), but plural in (4), i.e. nkwaraa 'children' and $\boldsymbol{w}$ ( ${ }_{3} \mathrm{PL}$ ). This is in contrast to English in which equivalent verbs, as shown in the translations, agree in number with their subject-NPs:

(3) akwaraa no nim dee J-re-ye

child DEF know what 3sg-PROG-do

'The child knows what he/she is doing.'

(4) n-kwaraa no nim de $\varepsilon$ wo-re-ye

PL-child DEF know what 3PL-PROG-do

'The children know what they are doing.'

The position here is that the concord errors (CEs) that both SPE and non-SPE speakers committed relate strongly to the fact that in their L1s no subject-verb agreement is required. In fact, it is this same feature of their L1s that has been identified as the source of the lack of subject-verb agreement in SPE itself (cf. Huber, 1999). In other words, the original source of the CEs in the written English of students cannot be SPE, which itself owes this characteristic to the students' L1s. It even appears that some speakers match the English nominal plural $\mathbf{- s}$ and the present tense singular $-\mathbf{s}$, because they are homophones, and go on to commit the type of error that a non-SPE speaker committed in the following example cited in Table 2 above:

(5) All the universities in the country does not accept D7, E8.

The position in this paper therefore contrasts that of Sey (1973), which is that the subjectverb agreement errors Ghanaians commit are not due to features of their L1s. However, the paper agrees with Odamtten, Denkabe and Tsikata (1994) that such errors ought not to be carried beyond the basic or second cycle level because a culture of reading and attention to the basics of the English language should cure these ailments before the tertiary level. 
Another recurrent type of error in the written English of students that has to do with the absence of a grammatical feature in their L1 is the use of wrong gender in pronoun reference. This type of error is illustrated with example (6) below from the chief examiners' report on the May/June 2013 examinations that complained about students' inability to observe gender distinctions in their pronoun usage:

(6) She was giving [sic] a beautiful dress by his father.

In the sentence above ${ }^{6}$, the masculine possessive adjective his is wrongly used as a referring expression that points back to the feminine subject pronoun antecedent she. Ghanaian languages do not reflect gender distinctions in their pronouns as is the case in English. In example (3) above, the Twi third person singular pronoun $\supset$ is ambiguous as one cannot tell whether it is masculine or feminine. The Ewe third person singular pronoun e is similarly ambiguous in example (7) below:
(7) e-fofo-a
fle
awu
nyuie ade
na-e.
3sg-father-DEF
buy
shirt fine INDEF
for 3 sg
'His/her father bought a beautiful dress for him/her.'

The point here is that this gender neutrality in L1 pronouns accounts for the type of error illustrated in (6) above; in other words, the error does not relate to SPE. Although SPE is English-based, it also shows gender neutrality, as seen in the SPE version of (7) in example (8) below. Here, im represents both possessive 'his' and 'her' while am represents both objective 'him' and 'her', and following Huber (1999) it can be argued that SPE owes its gender neutrality to its creators' L1s (such as Ewe):

(8) im popi buy am some beautiful dress.

3sg-father buy 3 sg some beautiful dress

'His/her father bought him/her a beautiful dress.'

As with the subject-verb agreement issue, this paper claims that it is not proper to fault SPE as the primary source of the lack of gender distinction being made by students in their written English when SPE itself arguably owes its gender neutrality to its creators' L1s. In other words, it can be said that the students' L1s ill-prepare them to observe gender distinctions in their pronoun usage in English and that this is why it is not only SPE speakers who may commit this type of error.

6. Unfortunately, no illustration of this type of error was found in the data because the subject matter of the essay, Koforidua Polytechnic, is a neuter gender. 
Spelling errors, especially WS (Wrong Spelling), may also be traced to causes other than the speaking of SPE. If the morphosyntactic features of SPE were to negatively affect the written Standard English (SE) of SPE speakers, SPE speakers would have been found to commit WS errors that are closely related to SPE. For example, a spelling like stan instead of the SE: stand would have been found. However, no such pidgin-related spellings were seen in the data. The spelling errors identified were common ones usually committed by all kinds of English language users, as is the case with the spelling of 'dare' as there by an SPE speaker (see the WS example in table 1) and 'renown' as renound by a non-SPE speaker (see the WS example in table 2). This type of spelling errors reflects how the writers most probably mispronounce the affected words. Indeed, Odamtten et al (1994) recorded many other spellings that point to this explanation, e.g. Febuary (February), here (hear), greatful (grateful), trast (trust), exercutive (executive), distruct (distract), altimate (ultimate), and discermination (dissemination).

Also noticed (see Table 5) are problems related to the use of upper case letters (PNC and WC) in both SPE speakers (committing 9 errors) and non-SPE speakers (committing 18 errors). At issue here is the question how SPE is responsible for these errors when it is non-SPE speakers who committed more of them. Even if SPE speakers were to have committed more of these errors it will still be difficult to fault SPE directly (i.e. rather than Standard English / SE) because these errors must arguably have been picked up in the context of writing rather than speaking.? The point here benefits from Weinreich's (1953) explanation regarding the cognitive strength of a bilingual's language of literacy over the language in which he is only orally competent. Weinreich (1953: 78) posits that "The visual reinforcement in the use of a language that a bilingual gets by reading and writing it may put that language in a dominant position over a purely oral one". It therefore seems more likely for the direction of transfer of this type of errors to be from SE to SPE.

Weinreich's view also sheds some light on abbreviation-related spelling errors - e.g. dat (for 'that'), dem (for 'them') - and errors involving the omission of subject pronouns e.g. when 'I am' becomes am and 'it is' becomes is - that are found in the data. It is the emergence of social media platforms such as text messaging, Whatsapp and Facebook that is largely responsible for the frequent use of such clipped words and abbreviated expressions, which reflect the phonology of the expressions instead of the proper orthography (Asinyor, 2012). Even though some of these forms (e.g. dat and dem) indeed appear in SPE writings, it is questionable to finger SPE as the primarily source of their emergence in formal SE writings when the language of most platforms is SE.

7. It is common knowledge that SPE is essentially an oral language and that many SPE speakers may not even know the writing formalities of this variety of language let alone transfer such formalities into their writing of Standard English. 


\section{Summary and Conclusion}

This paper highlighted the situation in Ghana-and similar concerns have been raised in Cameroon-where English is learned and used as a second (and official) language alongside varieties of an English-related pidgin and where the speaking of pidgin is routinely blamed for errors that learners of English, especially those in secondary and tertiary institutions, commit in their speech and writing. The paper investigated the accuracy of the said blame in the case of English in Ghana by posing the question, 'Is there a definite causal link between Ghanaian Pidgin English (specifically School Pidgin English / SPE) and the errors in Ghanaian students' written English?' The data analyzed were grammatical and spelling errors committed in essays written by members of two groups of students at a diploma awarding institution (Koforidua Polytechnic). In that institution, two groups comprising 15 members each (i.e. 15 students identified as familiar speakers of SPE and 15 students who claimed and were known not to speak SPE) were asked to write an essay on a common topic. It emerged that none of the type of errors identified in the essays was exclusively committed by the SPE speakers, a finding which suggests that there is hardly a definite causative relationship between speaking SPE and committing the errors. Rather, causal links were found to exist between the errors and (i) some grammatical features of the students' mother tongues (e.g. the lack of subjectverb agreement and the gender neutrality in pronouns characteristic of their mother tongues) and (ii) some writing systems they use conventionally on electronic media platforms. The logical conclusion drawn is that the learning of English in Ghana (and most likely in Cameroon) may improve if teachers are guided by (or come to terms with) these more plausible causes of their students' problems when they try to help them.

\section{References}

Adika, G.S.K. (2012). English in Ghana: Growth, Tensions, and Trends. International Journal of Language, Translation and Intercultural Communication, 1 (1), pp. 151-166.

Amoako, J. K. (1992). Ghanaian Pidgin English: In search of diachronic, synchronic, and sociolinguistic evidence. PhD thesis, University of Florida.

Anyidoho, A. (2002). Analysis of the writing of final year university students. Ghanaian Journal of English Studies, 1. pp. 58-72.

Asinyor, E. (2012). The effects of null-subject sentences constructions on learners' writing: A case of Koforidua Sectech students. MPhil thesis, University of Ghana, Legon.

Dako, K. (2002a). Pidgin as a gender specific language in Ghana. Ghanaian Journal of English Studies, 1.pp. 73-82. 
Dako, K. (2002b). Student pidgin (SPE): The language of the educated male elite. IAS Research Review, 18 (2), pp. 53-62.

Dako, K. (2013a). A masculine code encroached on by young women. In L. L. Atanga, S. E. Ellece, L. Liatosseliti, \& J. Sunderland (Eds.), Gender and Language in Sub-Saharan Africa, pp.217-231. Amsterdam: John Benjamins Publishing Company.

Dako, K. (2013b). Student Pidgin: A Ghanaian Pidgin-sound-alike youth language. In A. N. Mensah, J. A. Anderson, and P. K. Adika (Eds.), Ghanaian Voices on Topics in English Language and Literature, pp.147-16o. UK: Ayebia Clarke Publishing Limited.

Dako, K. and Yitah, H. (2012). Pidgin, 'Broken' English and 'othering' in Ghanaian literature. Legon Journal of the Humanities, Special Edition, pp. 202-230.

Desiree, P. (2004). Pidgin! me hear your speak, make me know why chaw students dey luv you. African Diaspora, 57 (online). Available at: www.digitalcollections.sit.educ/ african_diaspora. Accessed 22nd April. 2014.

Dzameshie, A.K. (2001). Attitudes towards Pidgin English among students in a Ghanaian university community. Paper presented at the School of Linguistics and Applied Languages Studies at the University of Reading.

Egblewogbe, E. Y. (1992). The use of broken English in higher institutions of learning and its implications for the future of education in Ghana. Unpublished paper presented at an inter-faculty lecture at the University of Ghana, February in Accra.

Eta, E. (2006). University of Buea's Anti-Pidgin campaign in pictures. Scribbles from the Den:

Archives, Commentaries, What Not. Available at: www.dibussi.com/2006/09/ubs antipidgin_.html. Accessed $18^{\text {th }}$ December, 2015.

Frimpong, G. K. (2012). Pidgin English in Ghanaian churches. Legon Journal of the Humanities Special Edition, pp. 117-201.

Huber, M. (1999). Ghanaian Pidgin English in its West African context. Philadelphia: John Benjamins Publishing Company.

Huber, M. (2014). A report on the use of English-lexified pidgins and creoles in education in four West African countries: Sierra Leone, Ghana, Nigeria and Liberia. Available at: http://www.hawii.edu/satocenter/pace. Accessed $18^{\text {th }}$ December, 2015. 
Odamtten H., Denkabe, A. and Tsikata, D. (1994). The problem of English Language skills at the University Level: A case study of first year law and humanities students at the University of Ghana, Legon Journal of the Humanities Vol. VII. pp. 95-125.

Rupp, L. (2013). The function of Student Pidgin in Ghana. English Today, 29, pp. 13-22.

Sey, K.A. (1973) Ghanaian English. London: Macmillan.

Weinreich, U. (1953). Languages in Contact, findings and problems. New York: Linguistic Circle of New York.

Wiredu, J. F. (2013). The nominal group in Ghanaian student pidgin: some preliminary observations. In Mensah, A. N., Anderson, J. A., and Adika P. K. (Eds.), Ghanaian Voices on Topics in English Language and Literature, pp. 161-185. UK: Ayebia Clarke Publishing Limited. 